\title{
The Italian Insurance Market
}

\author{
by Pier Carlo Romagnoli *
}

Private insurance in Italy is seriously handicapped by a number of political and economic factors which are not encountered in the majority of other European countries. The most important of these factors are :

1. the persistence of relatively low incomes in large areas of the country, resulting in a continuing low expenditure per head on insurance, about 125 dollars in 1982);

2. the existence of an extensive public social security system, which further reduces the scope for private insurance, especially in the life and sickness branches.

\section{Estimates for 1982}

Despite these basic factors, the Italian insurance market is growing slowly but steadily. The final statistics for 1982 are not yet available, but according to the provisional figures, relating only to direct Italian business, premium income in the life and damage branches last year passed the 10,000 billion lire mark ( $\$ 7.2$ billion) with an increase of $21.8 \%$ over 1981 .

The growth rate was therefore higher than that of the gross domestic product $(18.8 \%)$ or the cost of living $(16.3 \%)$. Premiums in the damage branches rose by $22.3 \%$ in current lire and by $5 \%$ in real terms, and in the life branch by $18.8 \%$ and $2 \%$ respectively.

\section{Comparison between 1977 and 1982}

During the period from 1977 to 1982, the rise in direct business (life and non-life premiums) was $144.5 \%$ in current lire and $12.1 \%$ in real terms. The satisfactory progress achieved during these years in the Italian insurance market is all the more striking when compared with the position in other European markets.

* Member of the Board, "Societa Reale Mutua di Assicurazioni ", Turin, and President of ANIA (National Association of Insurance Companies), Milano. 


\section{Three fundamental aspects}

The development of the Italian insurance market between 1977 and 1982 must be broken down into three fundamental branches : life, vehicle third party and other branches of non-life insurance. Direct Italian life premiums, despite the rise of $80.6 \%$ in current lire, showed a fall of $17.2 \%$ in real terms.

This step backwards was due to double-digit inflation.

Vehicle third-party premiums, which alone account for virtually $40 \%$ of total insurance business, rose by $127.7 \%$ in current lire and $4.5 \%$ in real terms. When it is borne in mind that the car population has grown far more over the last five years, not only in numbers but also in engine size, it must be concluded that the rise in premiums is more apparent than real. This leveling off is due to inadequacy of the rates authorised by the public authorities, for political rather than technical reasons. In fact, the vehicle third party insurance branch has been losing money for years.

\section{Development of the "non-vehicle" branches}

The over-all increase in premium income is therefore due to the marked development of the "non-vehicle" branches, which over the five years in question, recorded a rise in premium income of $187.5 \%$ in monetary terms and $31.9 \%$ in real terms.

The fact that with the growth of the "non-vehicle" damage branch alone, Italian insurers have succeeded in maintaining an over-all growth rate higher than the inflation rate means that the branch has displayed its ability to reac ${ }^{\star}$ with decisiveness and also inventiveness to the general economic crisis.

\section{Performance in 1981}

In order to give a more detailed picture of the Italian insurance market, it is necessary to analyse the over-all business performance (direct and indirect, Italian and foreign), the asset situation and the industry's financial record.

As the figures for 1982 will not be available until the end of June (when it will be possible to add up the balance sheets submitted to the annual general meetings of all the insurance firms), we have no option but to refer to the results for 1981. In that year, the direct and indirect premiums from Italian and foreign business amounted to 11,046 billion lire ( $\$ 7.9$ billion), of which 10,547 billion ( $\$ 7.5$ billion) were collected by Italian firms and 499 billion ( $\$ 356.4$ million) by foreign firms.

Over-all, the premiums from direct business amounted to 8,759 billion lire ( $\$ 6.3$ billion) and those from indirect business to 2,287 billion lire ( $\$ 1.6$ billion).

Outgoings have shown a steady rise. Claims paid in 1981 came to 4,916 billion lire i.e. they had more than doubled since 1977. As a proportion of direct premiums, outgoings i.e. all claims settled plus allocations to technical reserves, rose progressively between 1977 and 1981 from 71.6 to $82.1 \%$. 


\begin{tabular}{|c|c|c|c|c|c|}
\hline \multirow{2}{*}{$\begin{array}{l}\text { Outgoings under direct } \\
\text { Italian and foreign business, } \\
\text { life and non-life branches }\end{array}$} & 1977 & 1978 & 1979 & 1980 & 1981 \\
\hline & \multicolumn{5}{|c|}{ As $\%$ of premiums } \\
\hline Settlement of claims & 52.7 & 52.7 & 53.1 & 54.9 & 56.1 \\
\hline Allocations to technical reserves & 8.7 & 12.4 & 12.7 & 13.3 & 13.4 \\
\hline Allocations to loss reserves & 10.2 & 10.3 & 12.0 & .12 .8 & 12.6 \\
\hline Total outgoings & 71.6 & 75.4 & 77.8 & 81.0 & 82.1 \\
\hline
\end{tabular}

The rise amounts to eleven points on 11,000 billion lire; it is easy to calculate the rise in outgoings on the Italian market.

In 1981, industrial business, calculated as total net turnover of transfers, showed a loss of 435 billion lire. This figure, which is reached by deducting from the premiums received during the year the claims settled, commissions paid and the increase in technical reserves, did not, however, prevent the achievement of an annual profit for the year of 185.7 billion lire, as a result of the income from financial management (\$132.6 million).

\section{Industry profits}

Between 1977 and 1981, the profits of the insurance industry rose from 13.9 to 185.7 billion lire i.e. an increase of thirteen times in current lire. Net ordinary income went up from 487 to 1,371 billion lire i.e. an increase of $181 \%$ in current lire and of $50.5 \%$ in real terms. These figures bring out the decisive importance for balance sheets of financial earnings, which in turn were swollen by inflation.

Also between 1977 and 1981, general expenses showed only a moderate rise of $74.6 \%$ (from 519 to 906 billion lire). As a proportion of premium income, they therefore declined from 12.8 to $11.2 \%$.

The asset situation

As regards the asset situation, the total investments and liquidities of the insurance companies rose over the five years by $90.6 \%$ (from 7,918 to 15,092 billion lire). Holdings of securities with fixed yields in Italian lire and of shares in Italian companies and concerns more than doubled. Other forms of investment showed an average growth of $55 \%$. The value of property holdings in the balance sheets showed an increase of $33.6 \%$ in current lire but fell by $28.6 \%$ in real terms.

Property investments, in short, marked time compared with investments in bonds and shares $(+192.6 \%$ in current lire and $56.4 \%$ in real terms $)$. There was a particularly sharp rise in fixed-yield securities in Italian lire (up from 1,183 to 4,798 billion lire i.e. an increase of $305 \%$ ) which overtook property holdings for the first time 
(4,787 billion lire), despite the far-reaching re-evaluation of this item in our balance sheets.

Shareholdings in Italian companies also rose sharply, from 569 to 1,422 billion lire i.e. an increase of $149 \%$. The proportion of property investments to total investments and liquidities fell from $45.2 \%$ in 1977 to $31.7 \%$ in 1981.

The proportion of securities rose from $33.2 \%$ to $51 \%$. Fixed-yield securities in Italian lire, more particularly, went up from 14.9 to $31.8 \%$.

\section{Own assets and reserves}

Between 1977 and 1981, companies' own assets more than doubled, from 1,122.7 to 2,256 billion lire. Technical reserves net of transfers i.e. policy reserves plus premium reserves rose from 4,866 to 8,665 billion lire $(+78 \%)$.

Reserves for outstanding claims rose from 2,522 to 5,399 billion lire $(+114 \%)$.

\section{Italian business}

Further details are given below about the trend of Italian business in the non-life and life branches. As regards non-life, the premium income from direct and indirect Italian business, amounting in 1981 to 8,162 billion lire, had more than doubled compared with 1977. Premium income from direct business alone came to 7,277 billion lire i.e. an increase of $110 \%$ over 1977 . The provisions/direct premiums ratio was $22 \%$ in 1982 i.e. higher than the average for the quinquennium $(21.5 \%)$, while the overhead/premium ratio was $9.8 \%$ or less than the average for the quinquennium $(10.4 \%)$

\section{Non-life branch outgoings}

As regards technical costs, the ratio of insurance outgoings (settlement of claims plus allocations to technical reserves) to direct premiums rose from $73.4 \%$ in 1977 to $79.8 \%$ in 1981 .

\begin{tabular}{lrrrrr}
\hline Outgoings in non-life branches & 1977 & 1978 & 1979 & 1980 & 1981 \\
\cline { 2 - 6 } & \multicolumn{5}{c}{ \% of premium income } \\
\hline Settlement of claims $\ldots \ldots \ldots \ldots$ & 54.1 & 54.4 & 55.1 & 57.0 & 57.9 \\
Allocations to premium reserves $\ldots$ & 7.0 & 5.0 & 5.5 & 6.8 & 7.2 \\
Allocations to claims reserves $\ldots .$. & 12.3 & 12.0 & 13.9 & 15.0 & 14.7 \\
\cline { 2 - 6 } Total outgoings $\ldots \ldots \ldots \ldots$ & 73.4 & 71.4 & 74.5 & 78.8 & 79.8 \\
\hline
\end{tabular}

The ratio of insurance outgoings to premium income in the main non-life branches showed a general upward trend, to some extent because of a rise in the number of claims, but largely because of a fall in the premium rates. Vehicle third party and transport insurance, with ratios of 96.1 and $122.8 \%$ respectively, remained at all times above the average for the insurance market. 


\begin{tabular}{|c|c|c|c|c|c|}
\hline \multirow{2}{*}{$\begin{array}{l}\text { Outgoings in the main } \\
\text { non-life branches }\end{array}$} & 1977 & 1978 & 1979 & 1980 & 1981 \\
\hline & \multicolumn{5}{|c|}{$\%$ of premium income } \\
\hline Theft $\ldots \ldots \ldots$ & 63.4 & 60.7 & 62.0 & 60.3 & 62.1 \\
\hline Fire $\ldots$ & 53.5 & 43.2 & 44.7 & 52.8 & 56.4 \\
\hline Accident and disease .. & 70.4 & 53.4 & 53.1 & 54.0 & 55.4 \\
\hline Compulsory vehicle insurance .... & 84.0 & 82.8 & 89.9 & 94.3 & 96.1 \\
\hline Misc. third party insurance .. & 75.0 & 74.6 & 78.9 & 80.6 & 79.8 \\
\hline Transport $\ldots$ & 80.9 & 80.1 & 99.8 & 117.7 & 122.8 \\
\hline Total non-life branches ..... & 73.4 & 71.4 & 74.5 & 78.8 & 79.8 \\
\hline
\end{tabular}

\section{Income in non-life branches}

Net ordinary income over the quinquennium rose by $245 \%$ from 197 billion lire in 1977 (difference between 238.4 billion lire asset income and 41.4 billion lire asset outgoings) to 680.8 billion in 1981 (difference between 801.8 billion lire asset income and net lire asset outgoings, 121 billion), while its ratio to direct premium income went up from $5.7 \%$ to $9.4 \%$.

The net yield on insurance companies' assets is now $9.4 \%$. This rise in net asset yield has had an impact on financial performance - a loss of 8 billion lire in 1977 was converted into a profit of 157 billion in 1981 .

\section{Life insurance}

In life insurance, Italian direct and indirect business amounted in 1981 to $1,263,7$ billion lire, making an increase of $53.6 \%$ over 1977 . Premiums from direct business alone rose to $1,052.3$ billion lire, or an increase of $52 \%$ over 1977 . In real terms, however, direct premiums fell by $17.2 \%$.

\section{Halt to the downward trend}

The downward trend of the second half of the seventies in the life insurance branch leveled off from 1979 onwards, despite strong inflationary pressures, and there was an estimated increase in real terms of $2 \%$ in 1982 . This was mainly due to the industry's efforts to design and launch new insurance products. One yardstick of the life insurance branch is the yield of first-year premiums, which in 1981 amounted to 225.4 billion lire, or more than double the 1977 level. The ratio of first-year premiums to total direct premiums, which gives an index of new business, showed an increase of $15.9 \%$ in 1977 and of $21.4 \%$ in 1981.

The total ratio of provisions and overheads to direct premiums rose over the last three years from $33.2 \%$ to $40.6 \%$. 
This increase was broken down as follows : provisions rose from 21.4 to $27.4 \%$, while overheads rose from 11.9 to $13.2 \%$.

The ratio of overheads was of course influenced by the scissors effect of dependants' costs, which rose in real terms, and premiums, which declined in real terms.

“Life" outgoings

Claims arising out of direct business (sums and damages payable on maturity or redemption of policies and on death) plus allocations to policy reserve fund amounted cumulatively to $96.5 \%$ of direct premiums - higher than the average for the quinquennium $(95.5 \%$ ), which in itself was achieved by an improvement in efficiency.

\begin{tabular}{rrrrrrr}
\hline \multirow{2}{*}{ Life claims } & \multicolumn{1}{c}{1977} & 1978 & 1979 & 1980 & 1981 \\
\cline { 2 - 6 } & \multicolumn{4}{c}{$\%$ ratio to premiums } \\
\hline Claims settled $\ldots \ldots \ldots \ldots \ldots \ldots$ & 44.6 & 42.3 & 38.9 & 41.2 & 40.0 \\
Allocations to policy reserve $\ldots \ldots$ & 49.8 & 51.8 & 56.6 & 53.8 & 56.5 \\
\cline { 2 - 6 } Total outgoings $\ldots \ldots \ldots \ldots$ & 94.4 & 94.1 & 95.5 & 95.0 & 96.5
\end{tabular}

Net ordinary income showed an increase of $135 \%$ over the period 1977-81 from 225.9 to 530.8 billion lire, and its ratio to direct premiums rose from 32 to $50.4 \%$.

To conclude, a word on annual profits, which went up from 11.5 billion lire in 1977 to 60 billion lire in 1981 - an increase of $427 \%$. 